Article

\title{
Microstructure and Mechanical Property of Al6Si2Cu Alloy Subjected to Double-Solution Heat Treatment
}

\author{
Seongbin An, Minsuk Kim, Chaeeul Huh and Chungseok Kim *(D) \\ Department of Advanced Materials Science and Engineering, Chosun University, Gwangju 501-759, Korea; \\ bin@chosun.ac.kr (S.A.); okms1304@naver.com (M.K.); gjcodmf@naver.com (C.H.) \\ * Correspondence: chs2865@chosun.ac.kr; Tel.: +82-62-230-7197
}

check for

updates

Citation: An, S.; Kim, M.; Huh, C.; Kim, C. Microstructure and Mechanical Property of Al6Si2Cu Alloy Subjected to Double-Solution Heat Treatment. Metals 2022, 12, 18. https://doi.org/10.3390/ met12010018

Academic Editor: Babak Shalchi-Amirkhiz

Received: 8 November 2021 Accepted: 15 December 2021 Published: 22 December 2021

Publisher's Note: MDPI stays neutral with regard to jurisdictional claims in published maps and institutional affiliations.

Copyright: (c) 2021 by the authors. Licensee MDPI, Basel, Switzerland. This article is an open access article distributed under the terms and conditions of the Creative Commons Attribution (CC BY) license (https:/ / creativecommons.org/licenses/by/ $4.0 /)$.

\begin{abstract}
This study aims to develop the mechanical properties of the Al6Si2Cu aluminum alloy through the double-solution treatment. In addition to the $\mathrm{Al}$ matrix, large amounts of coarse eutectic $\mathrm{Si}, \mathrm{Al}_{2} \mathrm{Cu}$ intermetallic, and Fe-rich phases were generated through thermo-calc simulation in agreement with the equilibrium phases. The eutectic Si phase is fragmented and spheroidized by the solution treatment as the heat treatment temperature and time increase. The $\mathrm{Al}_{2} \mathrm{Cu}$ intermetallic phase is dissolved into the $\mathrm{Al}$ matrix, resulting in an increase in both strength and elongation. The second-step solution temperature at $525{ }^{\circ} \mathrm{C}$ should be an optimum condition for enhancing the mechanical properties of the $\mathrm{Al} 6 \mathrm{Si} 2 \mathrm{Cu}$ aluminum alloy.
\end{abstract}

Keywords: aluminum alloy; weight lightening; single-solution heat treatment; double-solution heat treatment

\section{Introduction}

Environmental problems, such as fossil fuel exhaustion, global warming, and air pollution, require specific tolerance standards for $\mathrm{CO}_{2}$ emissions or vehicle fuel consumption in the automobile industry $[1,2]$. There is an urgent need to study the weight reduction of automobiles that can reduce harmful gas emission and improve fuel efficiency in accordance with these social demands. Effective automobile weight reduction is more related to materials than structure design. For a long time, aluminum alloys have been studied as a lightweight material and widely applied as a substitute material. AlSiCu alloys have recently been used in cylinder blocks, cylinder heads, engine mount brackets, etc., bedue to their excellent mechanical properties and castability [3-6]. In general, the eutectic Si and $\mathrm{Al}_{2} \mathrm{Cu}$ phases of $\mathrm{AlSiCu}$ alloys are crystallized as coarse needles and coarse plates, respectively. When an external force is applied, a fracture can occur due to the stress concentration, which may restrict material usage [7].

Therefore, the alloy microstructure must be modified. To do this, the content of the alloying elements and the heat treatment process must be controlled. The heat treatment process technology for improving strength and elongation at the same time has yet to be well established, and many studies are needed. The single-solution heat treatment is normally limited to approximately $495^{\circ} \mathrm{C}$, since a higher temperature leads to the incipient melting of the copper-rich phase [8-10]. However, the single-solution heat treatment at temperatures of $495^{\circ} \mathrm{C}$ or less cannot maximize the dissolution of $\mathrm{Cu}$-rich phases, nor sufficiently modify the silicon particle morphology [11]. Therefore, the heat treatment duration is long, and modified elements, such as $\mathrm{Na}$ and $\mathrm{Sr}$, must be added. These disadvantages make the AlSiCu alloys impractical for use in industry. To compensate for these disadvantages, many investigators [12-14] have tried to utilize a solution heat treatment temperature higher than $495^{\circ} \mathrm{C}$. Previous studies reported the double-solution heat treatment in the range of $480-495^{\circ} \mathrm{C}$ for the first step and $515-530^{\circ} \mathrm{C}$ for the second step in A319 and A332 alloys. The double-solution treatment process reduces the $\mathrm{Cu}$-rich phase, yielding better ductility and strength compared to the single-solution heat treatment, and a better homogenization effect before aging heat treatment. 
The present study investigates the microstructural and mechanical properties of Al6Si2Cu alloy that undergoes the double-solution heat treatment.

\section{Materials and Methods}

The investigated Al6Si2Cu alloys were prepared by gravity cast into ingots $(670 \mathrm{~mm} \times 100 \mathrm{~mm} \times 40 \mathrm{~mm})$ to evaluate their microstructure and mechanical properties before and after heat treatment. The alloy composition was analyzed through inductively coupled plasma mass spectrometry (ICP-MS) (OPTIMA 4300 DV, Perkin Elmer, Wellesley, MA, USA). The chemical composition was 6.01Si, 2.09Cu, 1.03Fe, $0.19 \mathrm{Mn}$, and Al balance. Table 1 presents the first and second-step solution heat treatments applied to the $\mathrm{Al} 6 \mathrm{Si} 2 \mathrm{Cu}$ alloys. The solution temperature was carefully set to avoid the initial melting of the $\mathrm{Al}_{2} \mathrm{Cu}$ phase. The first-step solution temperature was $495^{\circ} \mathrm{C}$ below the melting temperature of the $\mathrm{Al}_{2} \mathrm{Cu}$ phase. The second-step solution was heat-treated to $515^{\circ} \mathrm{C}$ and $525{ }^{\circ} \mathrm{C}$ above the melting temperature of the $\mathrm{Al}_{2} \mathrm{Cu}$ phase to prevent incipient melting.

Table 1. Schedule of the double-solution heat treatment.

\begin{tabular}{cccccc}
\hline & \multicolumn{5}{c}{ Solution } \\
\cline { 2 - 6 } Specimen & \multicolumn{2}{c}{ First Step } & \multicolumn{2}{c}{ Second Step } & Quenching \\
\cline { 2 - 6 } & ${ }^{\circ} \mathbf{C}$ & $\mathbf{h}$ & ${ }^{\circ} \mathbf{C}$ & $\mathbf{h}$ & - \\
nys-cast & - & - & - & - & Water \\
T44A & 485 & 4 & - & 8 & Water \\
T44A-DS8A & 485 & 4 & 515 & 8 & Water \\
T44A-DS8B & 485 & 4 & 525 & - & Water \\
T44B & 495 & 4 & - & 8 & Water \\
T44B-DS8A & 495 & 4 & 515 & 8 & Water \\
T44B-DS8B & 495 & 4 & 525 & & \\
\hline
\end{tabular}

For the microstructure analysis, the specimens were observed using an optical microscope (OM) (AXIO, ZEISS, Oberkochen, Land Baden-Württemberg, Germany) after etching using Keller's solution $(1.25 \mathrm{~mL}$ nitric acid $+0.75 \mathrm{~mL}$ hydrochloric acid $+0.5 \mathrm{~mL}$ hydrofluoric acid $+47.5 \mathrm{~mL}$ distilled water). For a more precise investigation, several phases in the matrix were observed and analyzed through scanning electron microscopy (SEM) (DE/SUPRA 40VP, ZEISS, Oberkochen, Land Baden-Württemberg, Germany), energydispersive spectroscopy (EDS) (Apollo SDD, EDAX, Mahwah, NJ, USA), and electron probe micro analysis (EPMA) (Shimadzu, EPMA-1600, Kyoto, Japan). X-ray diffraction (XRD) (Rigaku, SmartLab X-ray diffractometer, Tokyo, Japan) was performed for the crystal structure analysis. The $2 \theta$ analysis was conducted from $30^{\circ}$ to $50^{\circ}$ using $\mathrm{CuK} \alpha$. The step size was $0.01^{\circ}$, and the scan step time was $1 \mathrm{~s}$. The hardness test for the evaluation of the mechanical properties was performed using a microhardness tester (Micro Vickers hardness Tester) (Shimadzu, HMV-G 21ST, Kyoto, Japan), and measured 20 times for each specimen at $5 \mathrm{~s}$ holding time with $1 \mathrm{~kg}$ load. The tensile test specimens were prepared in the form of a plate with a parallel portion $16.5 \mathrm{~mm}$ length, $5 \mathrm{~mm}$ width, and $3 \mathrm{~mm}$ thickness. A tensile tester (Table-top precision universal tester) (Shimadzu, AGS-20kNX, Kyoto, Japan) was used at $1 \mathrm{~mm} / \mathrm{min}$ strain rate at room temperature.

\section{Results and Discussion}

\subsection{Microstructure}

Figure 1 shows the microscopic observation of the surface microstructure of the as-cast specimen. The microstructure of the cast material depicted a typical dendrite structure. The secondary dendrite arm spacing measured by an image analyzer (I-Solution) (IMT i-Solution ver.11, Vancouver, BC, Canada) was $40 \mu \mathrm{m}$. The Al6Si2Cu alloys had two major Fe-Si intermetallic phases: $\alpha-\mathrm{Al}_{15}(\mathrm{Fe}, \mathrm{Mn})_{3} \mathrm{Si}_{2}$, which is known as the $\alpha$-Fe phase, and $\beta$ $\mathrm{Al}_{5} \mathrm{FeSi}$, which is known as the $\beta$-Fe phase. The $\alpha-\mathrm{Al}_{15}(\mathrm{Fe}, \mathrm{Mn})_{3} \mathrm{Si}_{2}$ phase had a dense form and did not cause crack formation in the casting process. In addition, the composition and 
shape may change depending on the solution conditions. On the contrary, the $\beta-\mathrm{Al} 5 \mathrm{FeSi}$ phase had a morphologically needle-shape microstructure. The $\beta$-Fe phase was brittle, and became a factor of lowering the mechanical properties of the cast material.

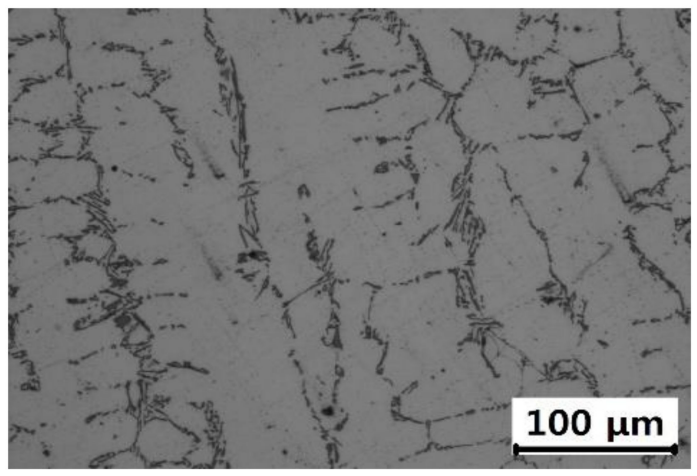

Figure 1. Optical micrograph of the as-cast Al6Si2Cu alloy showing the typical dendrite microstructure of the gravity casting process.

Figure 2 presents the backscattered electron (BSE) photographs of the gravity casting (as-cast) specimen and T44A-DS8A(first step solution heat treatment: $495^{\circ} \mathrm{C} 4 \mathrm{~h}$, second step solution heat treatment: $515^{\circ} \mathrm{C} 8 \mathrm{~h}$ specimen). Figure $2 \mathrm{a}, \mathrm{c}$ illustrate the four phases, that is, the Chinese-script shape $\alpha-\mathrm{Al}_{15}(\mathrm{Fe}, \mathrm{Mn})_{3} \mathrm{Si}_{2}$ phase, the needle-shape $\beta-\mathrm{Al}_{5} \mathrm{FeSi}$ phase, the plate-shape $\theta-\mathrm{Al}_{2} \mathrm{Cu}$, and the eutectic $\mathrm{Si}$ phase. BSEs are beam electrons reflected from the sample by elastic scattering. The BSE signal is strongly related to the atomic number $(Z)$ of the specimen. Typically, heavier elements can more strongly deflect incident electrons compared to lighter elements due to their larger nuclei. More backscattered electrons were emitted from the sample surface; hence, heavy elements such as $\mathrm{Cu}$ and Fe, which had atomic numbers of $Z=29$ and $Z=26$, respectively, appeared bright in an SEM image compared to lighter elements, such as aluminum $(Z=13)$ and silicon $(Z=14)$. The EDS analysis of each phase was then performed. Table 2 presents the results, which were consistent with those of the $\alpha-\mathrm{Al}_{15}(\mathrm{Fe}, \mathrm{Mn})_{3} \mathrm{Si}_{2}$ and $\beta-\mathrm{Al}_{5} \mathrm{FeSi}$ EDS analyses reported by Ceschini et al. [15]. Figure $2 b$,d depict enlarged images of $\theta-\mathrm{Al}_{2} \mathrm{Cu}$. In the as-cast specimens, $\theta-\mathrm{Al}_{2} \mathrm{Cu}$ existed in coarse form, but segmented and dissolved after the solid solution treatment. These microstructure observations showed no evidence of incipient melting phenomena, despite the second-step solution temperature being higher than the melting temperature of the $\mathrm{Al}_{2} \mathrm{Cu}$ phase.

Table 2. Chemical compositions of the main intermetallic phases in the as-cast Al6Si2Cu alloy (wt.\%).

\begin{tabular}{ccccccc}
\hline Phase & $\mathbf{S i}$ & $\mathbf{C u}$ & Fe & Mn & Al & Point \\
\hline$\alpha$ & 10.7 & - & 22.0 & 8.6 & 56.6 & $\mathrm{Al}_{15}\left(\mathrm{Fe}, \mathrm{Mn}_{3} \mathrm{Si}_{2}\right.$ \\
$\beta$ & 17.5 & - & 23.1 & 2.6 & 56.6 & $\mathrm{Al}_{5} \mathrm{FeSi}$ \\
$\mathrm{Si}$ & 93.6 & - & - & - & 6.3 & $\mathrm{Si}$ \\
$\theta$ & - & 51.3 & - & - & 48.6 & $\mathrm{Al}_{2} \mathrm{Cu}$ \\
\hline
\end{tabular}

Figure 3 shows the morphology of the $\theta-\mathrm{Al}_{2} \mathrm{Cu}$ phase for each solution treatment condition. The coarse $\theta-\mathrm{Al}_{2} \mathrm{Cu}$ phase of the as-cast ingot generally incurred the incipient melting in the $\mathrm{Al}$ matrix when heat-treated above $520^{\circ} \mathrm{C}$. This defect was caused by the simultaneous decrease of the strength and ductility of the aluminum alloy. This study solves the abovementioned problem on heat treatment by using the double-solution heat treatment method before and after the melting point of the $\theta-\mathrm{Al}_{2} \mathrm{Cu}$ phase. In the first-step solution heat treatment, many impurity elements in the microstructure were redissolved into the $\mathrm{Al}$ matrix, and the $\theta-\mathrm{Al}_{2} \mathrm{Cu}$ phase was partially dissolved, as shown in Figure 3 , contributing to the solid solution hardening effect. In the second-step heat treatment, the coarse form of the $\theta-\mathrm{Al}_{2} \mathrm{Cu}$ phase became more fragmented and finer, and dissolved as 
the temperature and time of the solution treatment increased as shown in Figure 3d,g. Therefore, defects (e.g., pores) caused by incipient melting were not observed.
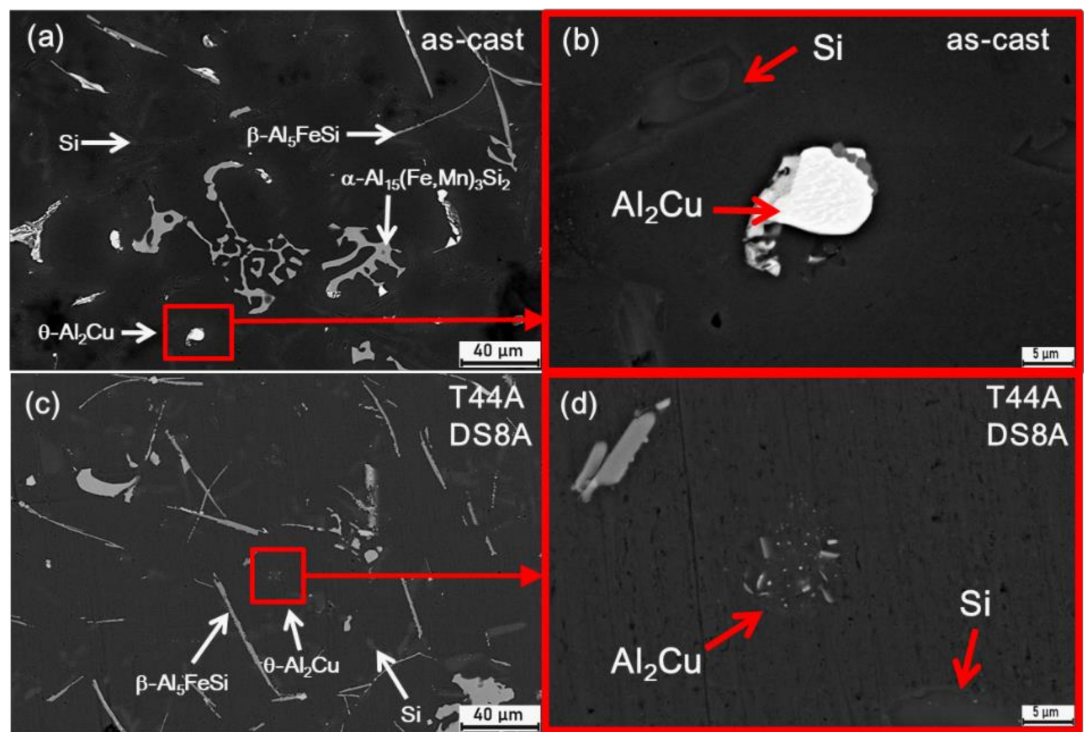

Figure 2. Microstructural observation of the Al6Si2Cu alloy: (a) BSE(backscatter electron) micrograph showing various as-cast phases; (b) BSE micrograph showing the $\mathrm{Al}_{2} \mathrm{Cu}$ and $\mathrm{Si}$ phases of as-cast; (c) BSE micrograph showing various T44A-DS8A phases; and (d) BSE micrograph showing the $\mathrm{Al}_{2} \mathrm{Cu}$ and Si phases of T44A-DS8A.

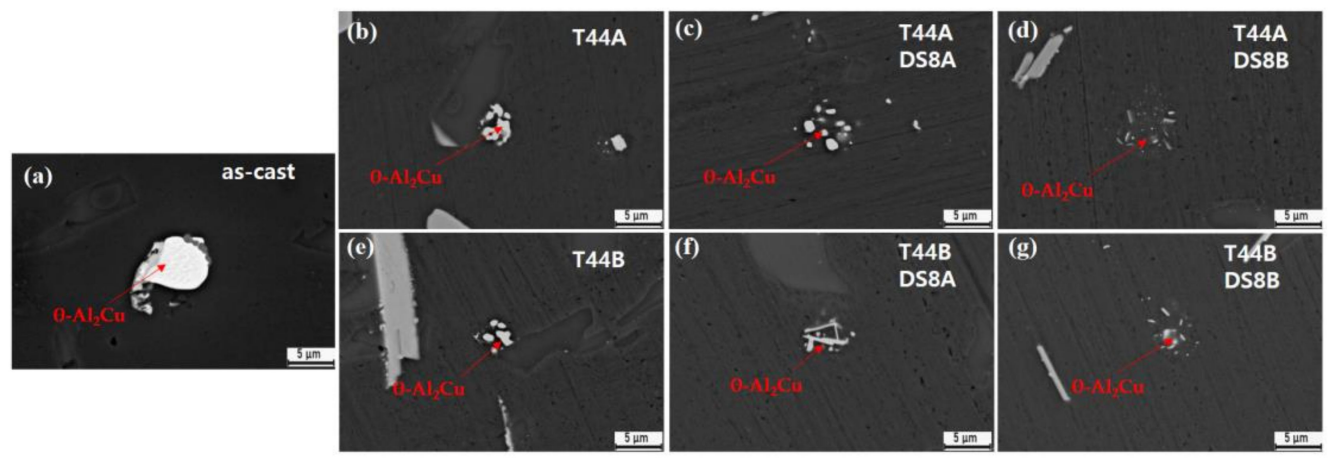

Figure 3. BSE micrographs of the Al6Si2Cu alloy showing dissolution of $\mathrm{Al} 2 \mathrm{Cu}$ phase: (a) coarse Al2Cu phase in as-cast sample, (b) T44A, (c) T44A-DS8A, (d) T44A-DS8B, (e) T44B, (f) T44B-DS8A, and (g) T44B-DS8B.

Figure 4 shows the results of the EPMA analysis of each phase of the as-cast specimen. The elemental distributions of $\mathrm{Al}, \mathrm{Cu}, \mathrm{Fe}, \mathrm{Mn}$, and $\mathrm{Si}$ in the matrix are also presented. The BSE micrographs present $\alpha-\mathrm{Al}_{15}(\mathrm{Fe}, \mathrm{Mn})_{3} \mathrm{Si}_{2}, \beta-\mathrm{Al}_{5} \mathrm{FeSi}, \theta-\mathrm{Al}_{2} \mathrm{Cu}$, and eutectic $\mathrm{Si}$. Fe and $\mathrm{Mn}$ were concentrated in the Chinese-script-shaped $\alpha$-Fe phase, while Fe and $\mathrm{Si}$ were distributed in the needle-shape $\beta$-Fe phase.

Figure 5 depicts the equilibrium phase of the $\mathrm{Al} 6 \mathrm{Si} 2 \mathrm{Cu}$ alloy by thermodynamic calculations. The thermodynamic calculation results showed that the $\mathrm{Al}_{15}(\mathrm{Fe}, \mathrm{Mn})_{3} \mathrm{Si}_{2}$ and $\beta-\mathrm{Al}_{5} \mathrm{FeSi}$ phases existed in the solution treatment temperature range. In addition, the melting temperature of $\theta-\mathrm{Al}_{2} \mathrm{Cu}$, which was the basis for the first- and second-step solution temperatures herein, was approximately $510^{\circ}$. 

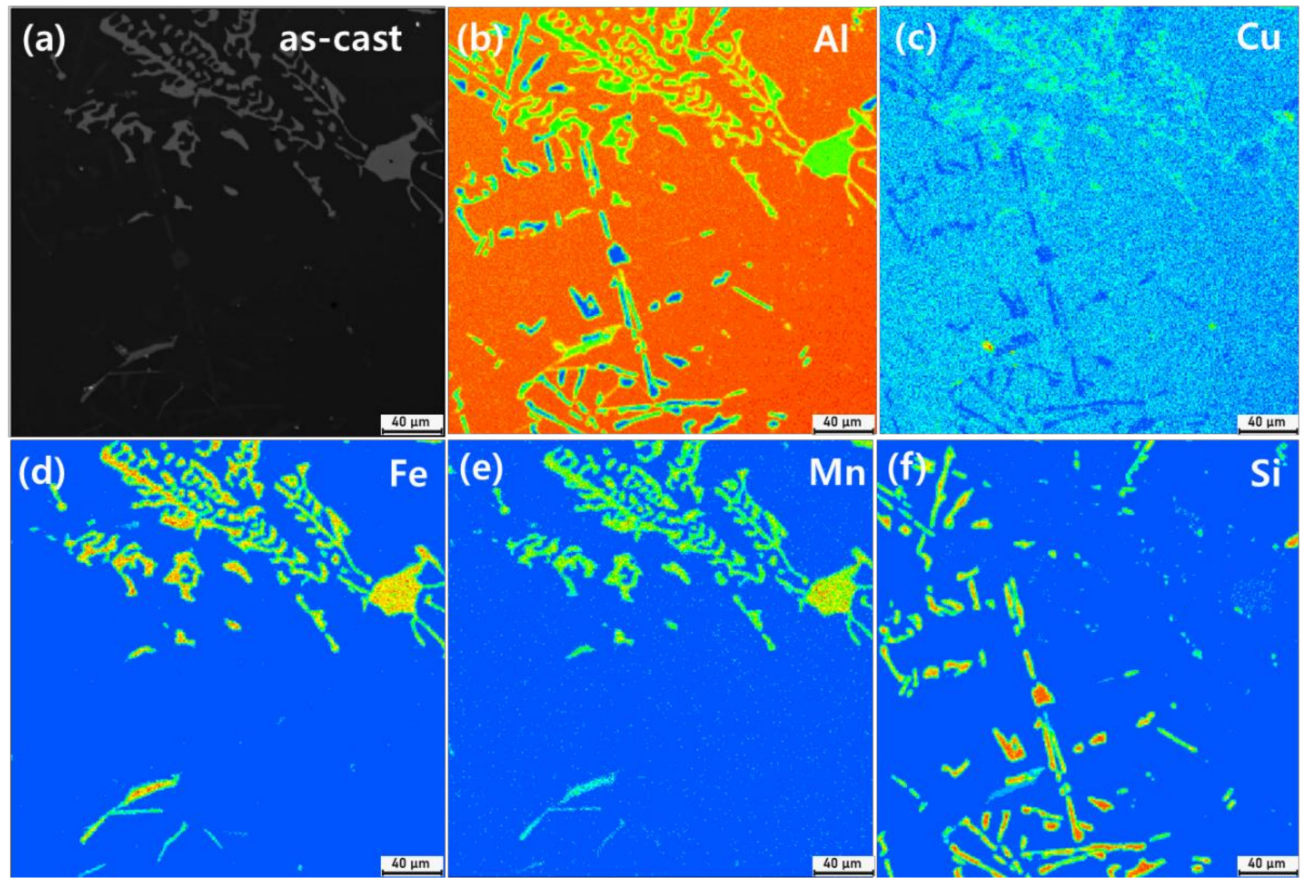

Figure 4. EPMA analysis of the as-cast Al6Si2Cu alloy (wt.\%): (a) as-cast, (b) $\mathrm{Al}$, (c) $\mathrm{Cu},(\mathbf{d}) \mathrm{Fe},(\mathbf{e}) \mathrm{Mn}$, (f) Si.

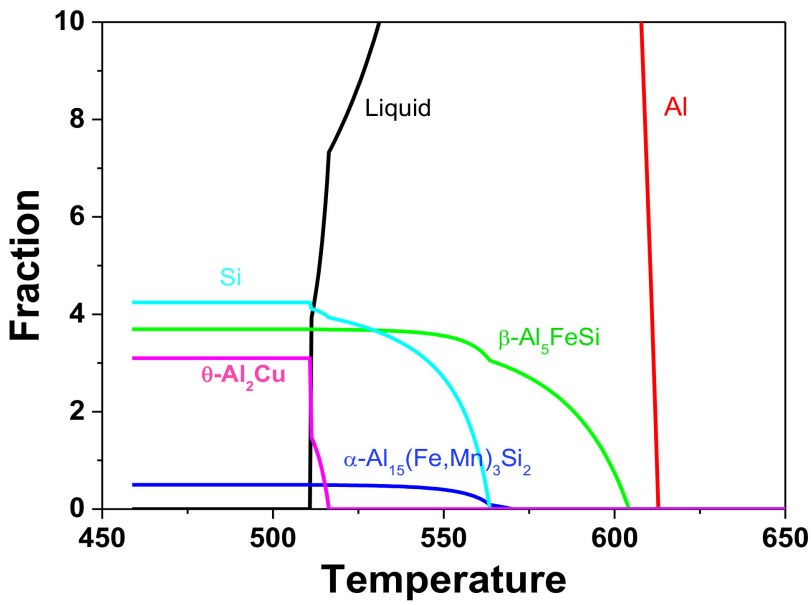

Figure 5. Mass-fraction of the equilibrium phase diagram of the Al6Si2Cu alloy computed through thermo-calc calculation showing the $\alpha$ and $\beta$ Fe-rich phase, $\mathrm{Cu}$-rich phase, and Si phase.

Figure 6 displays the results of the microscopic observation of the microstructure changes, such as Fe-rich phase and Si particle according to the as-cast and solution treatment conditions. In general, as the heat treatment temperature and time increased, the average area of the Si particles decreased, and the aspect ratio increased, as clearly shown in the phase micrographs. The Si particle changed its atomic position by diffusing on the surface, leaving the silicon lattice by interdiffusion, and migrating through aluminum at the $\mathrm{Al}-\mathrm{Si}$ interface in the phase boundary $[16,17]$. These diffusions were active above $500{ }^{\circ} \mathrm{C}$, which was consistent with the equilibrium phase diagram in Figure 5. The Si particles were spheroidized from the edge by diffusion when the heat treatment temperature was higher than $500{ }^{\circ} \mathrm{C}$. 


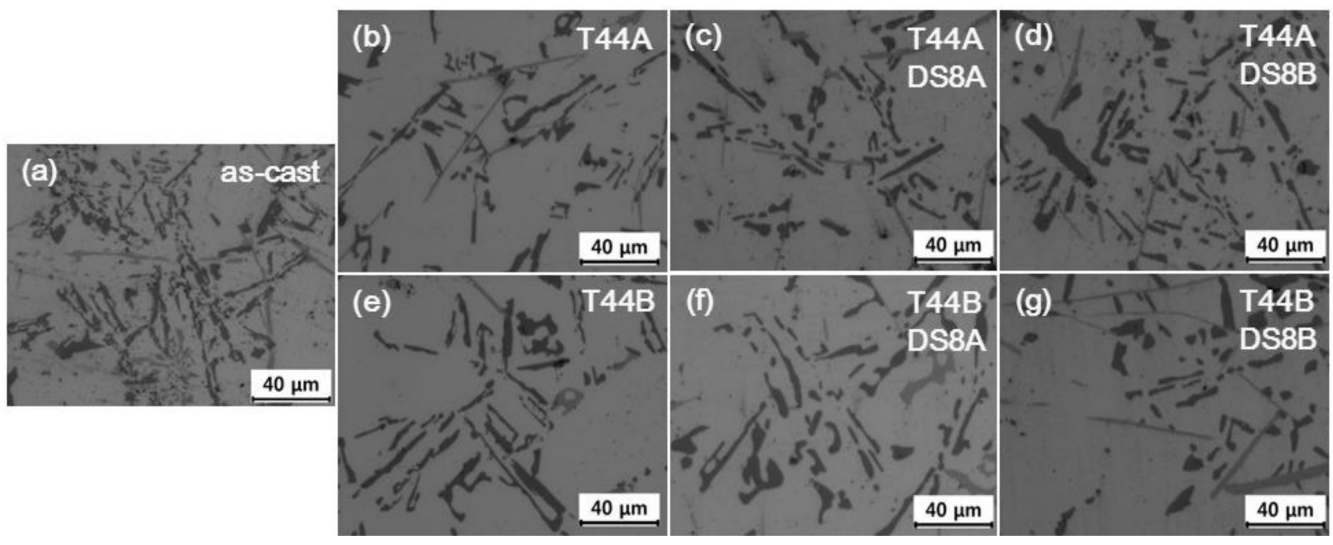

Figure 6. Microstructure of the Al6Si2Cu alloys after different solution treatments: (a) as-cast; (b) T44A; (c) T44A-DS8A; (d) T44A-DS8B; (e) T44B; (f) T44B-DS8A; and (g) T44B-DS8B.

Table 3 shows the quantitative evaluation results of the Si phase after the solution treatment, which were measured by an image analyzer (I-Solution) (IMT i-Solution ver.11, Vancouver, BC, Canada), showing the mean area of the Si particles, aspect ratio, and increase in the aspect ratio compared with those of the as-cast sample value. The aspect ratio of silicon particles was image analyzed using the image recognition function of $\mathrm{i}$ solution software(I-Solution) (IMT i-Solution ver.11, Vancouver, BC, Canada). The aspect ratio is the ratio of width to height, and the software automatically recognizes the image of dark Si particles that are distinct from the Al matrix and Fe-rich phase. The average value was measured by calculating the ratio of horizontal and vertical pixels of the recognized Si particle image. The mean area of the eutectic Si phase was decreased by the solution treatment, and depended on temperature and time. The aspect ratio of the eutectic $\mathrm{Si}$ particles increased by approximately $130 \%$ in T44A and T44B, compared to those in the as-cast specimen. That of DS8A increased by approximately $60 \%$ compared to that in the first-step solution treatment, while that in DS8B increased by more than $100 \%$. The shape of the brittle Si phase in the aluminum alloy was spheroidized; thus, the elongation and the toughness of this $\mathrm{Al} 6 \mathrm{Si} 2 \mathrm{Cu}$ alloy were thought to have improved, resulting in the enhancement of both ductility and fatigue strength.

Table 3. Silicon particle characteristic of the alloy after the solution treatment.

\begin{tabular}{cccccccc}
\hline Specimen & As-Cast & T44A & T44A-DS8A & T44A-DS8B & T44B & T44B-DS8A & T44B-DS8B \\
\hline Mean Area & 47.1 & 31.4 & 29.6 & 26.1 & 31.7 & 25.8 & 20.6 \\
$\quad\left(\right.$ um $\left.^{2}\right)$ & 0.16 & 0.37 & 0.59 & 0.77 & 0.37 & 0.62 & 0.83 \\
Aspect Ratio & - & $130 \% \uparrow$ & $268 \% \uparrow$ & $381 \% \uparrow$ & $130 \% \uparrow$ & $287 \% \uparrow$ & $418 \% \uparrow$ \\
\hline
\end{tabular}

\subsection{XRD Analysis}

Figure 7 illustrates the diffraction peaks of $\mathrm{Si}, \mathrm{Al}$, and $\theta-\mathrm{Al}_{2} \mathrm{Cu}$. The $\theta-\mathrm{Al}_{2} \mathrm{Cu}$ diffraction peaks were observed at $2 \theta=42.04(220), 2 \theta=43.04(112)$, and $2 \theta=47.28$ (310). The diffraction peaks of the (220) and (112) planes of the $\mathrm{Al}_{2} \mathrm{Cu}$ intermetallic phase in the as-cast specimen were clearly observed before the solution heat treatment. However, these diffraction peaks became weak and disappeared from the solution specimen, T44A-DS8A. The $\mathrm{Al}_{2} \mathrm{Cu}$ phase was usually dissolved into the $\mathrm{Al}$ matrix during the solid solution treatment (Figure 3). The $\mathrm{Al}_{2} \mathrm{Cu}$ phase dissolution in the matrix may lead to a supersaturation of the $\mathrm{Cu}$ atoms into the Al lattice. This is enough to deform the Al lattice, causing an increase in the mechanical strength of the $\mathrm{Al} 6 \mathrm{Si} 2 \mathrm{Cu}$ aluminum alloy. 


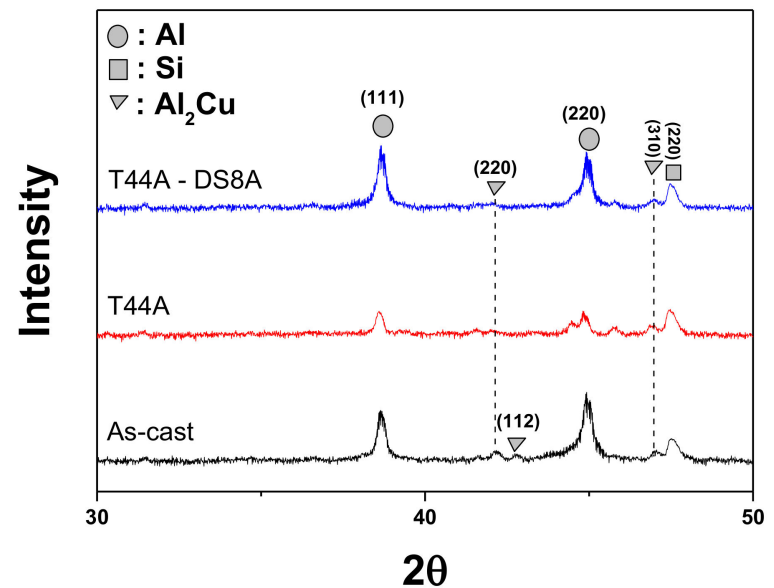

Figure 7. XRD (X-ray diffraction) profiles of the Al6Si2Cu alloy showing the diffraction peaks of the typical solution treatment.

\subsection{Mechanical Properties}

Figure 8 shows the results of the micro-Vickers hardness test of the heat-treated Al6Si2Cu alloy with each load (i.e., $19.61 \mathrm{~N}$ and $245 \mathrm{mN}$ ). The alloy hardness after the heat treatment increased by approximately $30 \%$ compared with that of the as-cast specimen, since the coarse $\theta-\mathrm{Al}_{2} \mathrm{Cu}$ particles that precipitated in the ingot did not contribute to the precipitation hardening. It is, however, thought that the hardness increased due to the solid solution hardening effect, as the $\mathrm{Cu}$ atoms were dissolved in the matrix after the solution treatment. As shown in Figure 8a, the indenter size was approximately $60 \mu \mathrm{m}$ when the load was $19.61 \mathrm{~N}$. In other words, hardness depended on several intermetallic and Si phases, as well as on the $\mathrm{Al}$ matrix. The intermetallic and eutectic Si phases and the Al matrix were measured at the same time. The hardness of the first- and second-step solution-treated specimens was higher than that of the as-cast specimen. Figure $8 \mathrm{~b}$ shows the measured $\mathrm{Al}$ matrix hardness depicting that the hardness of the first- and second-step solution-treated specimens significantly increased.
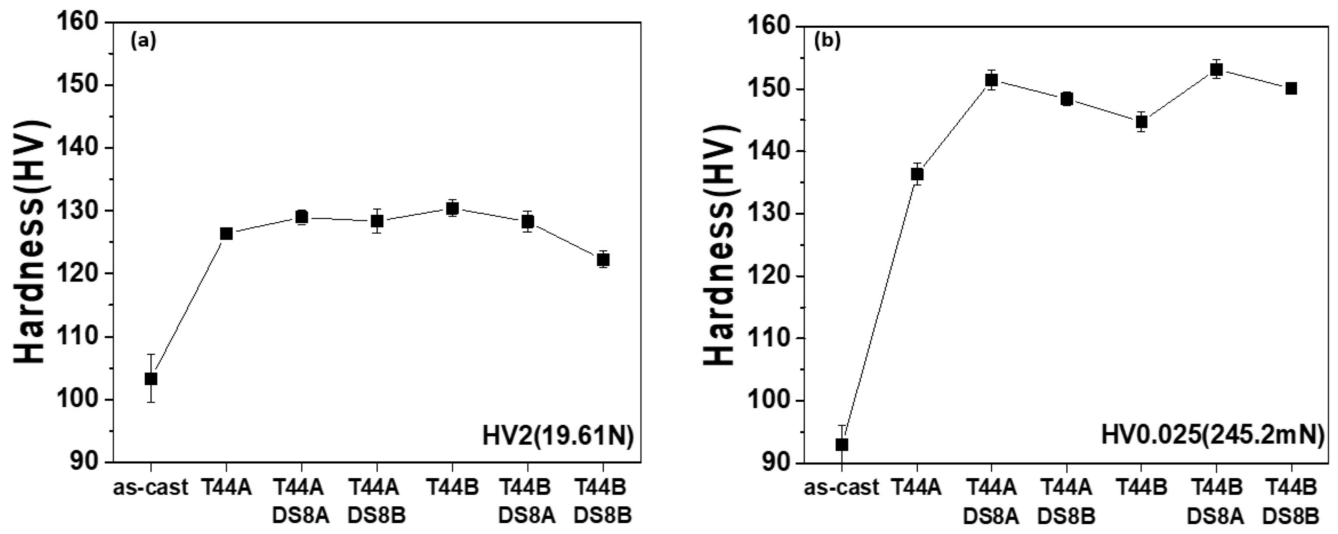

Figure 8. Micro-Vickers hardness of the alloys after various solution treatment schedules: (a) hardness for $2 \mathrm{~kg}$ load and (b) hardness of the $\mathrm{Al}$ matrix for $25 \mathrm{~g}$ load.

Figure 9 depicts the tensile test results obtained at various solution heat treatments showing the mechanical properties (e.g., UTS, YS, and elongation) at each solution treatment. The mechanical strength after the second-step solution heat treatment increased the ultimate tensile strength from $185 \mathrm{MPa}$ to $248 \mathrm{MPa}$, the yield strength from $152 \mathrm{MPa}$ to $181 \mathrm{MPa}$, and the elongation from $1.36 \%$ to $2.65 \%$ compared with the as-cast specimen. Figure $9 \mathrm{~b}$ shows the typical flow curves of as-cast, T44A-DS8B, and T44B-DA8B samples. 
The tensile strength and elongation of T44B-DA8B sample is higher than that of the as-cast and T44A-DS8B samples. These results are attributed to the $\mathrm{Cu}$ atoms being dissolved into the Al matrix without defect by the double-solution heat treatment, which contributed to the solid solution hardening, spheroidized shape of the brittle Si phase, and improved alloy elongation and toughness.

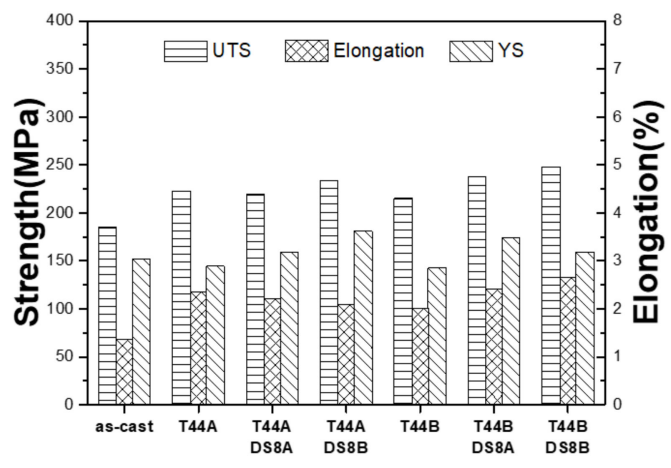

(a)

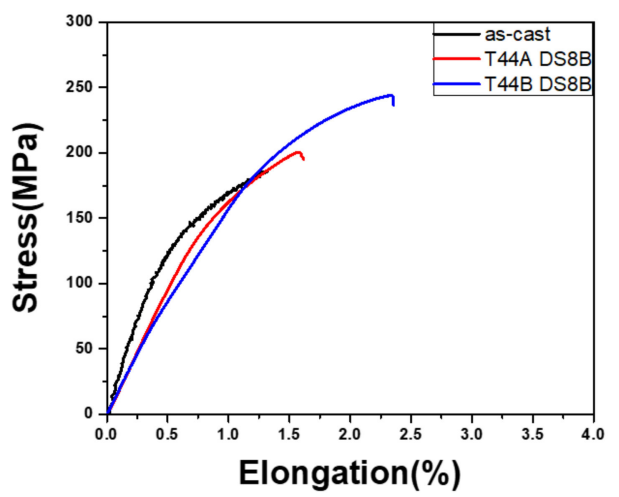

(b)

Figure 9. Tensile properties of the alloys after various solution treatments: (a) mechanical data at each heat treatment condition; UTS (ultimate tensile strength) elongation, YS (yeild strength) and (b) flow curves of typical sample condition.

\section{Conclusions}

This study presents the double-solution heat treatment on the microstructure and mechanical properties of the Al6Si2Cu alloys. The following conclusions are drawn:

1. The microstructure of the gravity-casted Al6Si2 $\mathrm{Cu}$ alloys was investigated. The Chinese-script shape $\alpha-\mathrm{Al}_{15}(\mathrm{Fe}, \mathrm{Mn})_{3} \mathrm{Si}_{2}, \beta-\mathrm{Al}_{5} \mathrm{FeSi}$ phase, and $\theta-\mathrm{Al}_{2} \mathrm{Cu}$ and eutectic Si phases were observed and analyzed in agreement with the thermodynamically calculated equilibrium phase diagram.

2. The XRD analysis depicted that the diffraction peaks of the (220) and (112) plane of the $\mathrm{Al}_{2} \mathrm{Cu}$ phase were observed in the gravity-cast specimens, but were not found in the solution treatment due to the $\mathrm{Al}_{2} \mathrm{Cu}$ phase dissolution into the $\mathrm{Al}$ matrix.

3. The double-solution heat treatment process was enough to dissolve the $\theta-\mathrm{Al}_{2} \mathrm{Cu}$ phase into the $\mathrm{Al}$ matrix without leaving any defects (e.g., pores) caused by the incipient melting of the $\theta-\mathrm{Al}_{2} \mathrm{Cu}$ phase.

4. As the heat treatment temperature and time increased, the Si particles were spheroidized; the average area of the Si particles decreased by approximately 56\%; and the aspect ratio increased by approximately $418 \%$.

5. The mechanical properties increased after the double-solution heat treatment. The ultimate tensile strength and elongation of the T44B-DS8B specimen increased by up to $34 \%$ and $95 \%$, respectively.

Author Contributions: Conceptualization, C.K.; methodology, C.K., S.A., M.K. and C.H.; software, S.A. and M.K.; validation, C.K. and S.A.; formal analysis, S.A. and C.H.; investigation, C.K. and S.A.; data curation, C.H. and S.A.; writing — original draft preparation, S.A.; writing - review and editing, S.A. and C.K.; visualization, S.A. and M.K.; supervision, C.K.; project administration, C.K.; funding acquisition, C.K. This paper was prepared the contributions of all authors. All authors have read and agreed to the published version of the manuscript.

Funding: This research was funded by Chosun University (2020).

Institutional Review Board Statement: Not applicable.

Informed Consent Statement: Not applicable.

Data Availability Statement: Not applicable. 
Acknowledgments: This study was supported by a research fund from Chosun University (2020).

Conflicts of Interest: The authors declare no conflict of interest.

\section{References}

1. Al-Alawi, B.M.; Bradley, T.H. Analysis of corporate average fuel economy regulation compliance scenarios inclusive of plug in hybrid vehicles. Appl. Energy 2014, 113, 1323-1337. [CrossRef]

2. Kim, G.T. High strength aluminum alloy for die casting. J. Korea Foundry Soc. 2011, 31, 101-105. [CrossRef]

3. Rohatgi, P.K.; Nath, D.; Singh, S.S.; Keshavaram, B.N. Factors affecting the damping capacity of cast aluminium-matrix composites. J. Mater. Sci. 1994, 29, 5975-5984. [CrossRef]

4. $\quad$ Li, Y.; Yang, Y.; Wu, Y.; Wang, L.; Liu, X. Quantitative comparison of three Ni-containing phases to the elevated-temperature properties of Al-Si piston alloys. Mater. Sci. Eng. 2010, 527, 7132-7137. [CrossRef]

5. Lei, J.; Li, N.; Rao, M.C. Development of heat-resisting aluminum alloy material for pistons. Adv. Mater. Res. 2008, 51, 105-110. [CrossRef]

6. Yao, J.Y.; Taylor, J.A. Characterisation of intermetallic particles formed during solution treatment of an $\mathrm{Al}-7 \mathrm{Si}-0.4 \mathrm{Mg}-0.12 \mathrm{Fe}$ alloy. J. Alloys Compd. 2012, 519, 60-66. [CrossRef]

7. Sigworth, G.K. The modification of Al-Si casting alloys: Important practical and theoretical aspects. Int. J. Met. 2008, 2, 19-40. [CrossRef]

8. Narayanan, L.A.; Samuel, F.H.; Gruzleski, J.E. Dissolution of iron intermetallics in Al-Si Alloys through nonequilibrium heat treatment. Metall. Mater. Trans. A 1995, 26, 2161-2174. [CrossRef]

9. Sokolowski, J.H.; Sun, X.; Byczynski, G.; Northwood, D.O.; Penrod, D.E.; Thomas, R.; Esseltine, A. The removal of copper-phase segregation and subsequent improvement in the mechanical properties of casting 319 aluminum alloy by a Double heat treatment. J. Mater. Process. Technol. 1995, 53, 385-392. [CrossRef]

10. Djurdjevic, M.; Stockwell, T.; Sokolowski, J. The effect of strontium on the microstructure of the aluminium-silicon and aluminiumcopper eutectics in the 319 aluminium alloy. Int. J. Cast Met. Res. 1999, 12, 67-73. [CrossRef]

11. Sokolowski, J.H.; Djurdjevic, M.B.; Kierkus, C.A.; Northwood, D.O. Improvement of 319 aluminum alloy casting durability by high temperature solution treatment. J. Mater. Process. Technol. 2001, 109, 174-180. [CrossRef]

12. Samuel, A.M.; Gauthier, J.; Samuel, F.H. Microstructural aspects of the dissolution and melting of $\mathrm{Al}_{2} \mathrm{Cu}$ phase in $\mathrm{Al}-\mathrm{Si}$ alloys during solution heat treatment. Metall. Mater. Trans. A 1996, 27, 1785-1798. [CrossRef]

13. Wang, G.; Bian, X.; Wang, W.; Zhang, J. Influence of $\mathrm{Cu}$ and minor elements on solution treatment of $\mathrm{Al}-\mathrm{Si}-\mathrm{Cu}-\mathrm{Mg}$ cast alloys Mater. Lett. 2003, 57, 4083-4087. [CrossRef]

14. Azmah Hanim, M.A.; Chang Chung, S.; Khang Chuan, O. Effect of a Double solution heat treatment on the microstructure and mechanical properties of 332 aluminium silicon cast alloy. Mater. Des. 2011, 32, 2334-2338. [CrossRef]

15. Ceschini, L.; Boromei, I.; Morri, A.; Seifeddine, S.; Svensson, I.L. Microstructure, tensile and fatigue properties of the Al-10\%Si2\%Cu alloy with different Fe and Mn content cast under controlled conditions. J. Mater. Process. Technol. 2009, 209, 5669-5679. [CrossRef]

16. Ogris, E.; Wahlen, A.; Lüchinger, H.; Uggowitzer, P.J. On the silicon spheroidization in Al-Si alloys. J. Light Met. 2002, 2, 263-269. [CrossRef]

17. Wang, J.; Zhu, J.; Liu, Y.; Peng, H.; Su, X. Effect of spheroidization of eutectic Si on mechanical properties of eutectic Al-Si alloys. J. Mater. Res. 2018, 33, 1773-1781. [CrossRef] 